\title{
LEVEL OF ESTROGEN HORMONE AND ESTRUS PERFORMANCE OF DIFFERENT POSTPARTUM ESTRUS OF JAWA RANDU GOAT
}

\author{
A. D. Tanjung, E. T. Setiatin and D. Samsudewa \\ Faculty of Animal and Agricultural Sciences, Diponegoro University, \\ Tembalang Campus, Semarang 50275, Central Java - Indonesia \\ CorrespondingE-mail : etsetiatin@gmail.com
}

Received April 13, 2015; Accepted May 24, 2015

\begin{abstract}
ABSTRAK
Penelitian ini bertujuan untuk mengetahui kualitas reproduksi kambing Jawa Randu dengan estrus postpartum (EPP) abnormal dibandingkan dengan kambing Jawa Randu dengan EPP normal ( $\mathrm{n}=16$ kambing) dilihat dari kadar hormon estrogen dan tampilan estrus. Data yang diperoleh dianalisis secara deskriptif dan secara non parametrik menggunakan Mann Whitney U-test dengan bantuan Statistical Package for the Social Science (SPSS) 16. Hasil analisis deskriptif pada kadar hormon estrogen menunjukkan bahwa EPP normal memiliki kadar yang lebih tinggi $(133,8 ; 141,5 ; 155,6 ; 162 ; 25,167 ; 75$ pg/mL) dibandingkan dengan kadar hormon estrogen kambing Jawa Randu EPP abnormal $(109,9$; $111,35 ; 101,2 ; 132,2 ; 142,45 \mathrm{pg} / \mathrm{mL})$. Hasil analisis Mann Whitney U-test untuk ferning dan kelimpahan lendir serviks menunjukkan tidak terdapat perbedaan antara kambing Jawa Randu EPP normal dibandingkan kambing Jawa Randu EPP abnormal. Jawa Randu dengan EPP normal mempunyai kadar estrogen yang lebih tinggi dibandingkan dengan EPP abnormal. Tetapi, kelimpahan dan lendir serviks antara kedua kelompok kambing tidak berbeda.
\end{abstract}

Kata kunci : kambing Jawa Randu, estrus postpartum, estrogen, lendir serviks, ferning

\begin{abstract}
The purpose of this research was to determine the reproductive quality of normal compared with abnormal postpartum estrus (PPE) of Jawa Randu Goats $(n=16$ goats) on estrogen hormon level and estrus profile. Total samples were 16 Jawa Randu goats. The data were analyzed descriptively and non parametric data were analyzed using Mann Whitney U-test of Statistical Package for the Social science (SPSS) 16. Descriptive statistics was used on estrogen hormone and resulting that normal postpartum estrus (PPE) Jawa Randu Goats had a better level $(133.8 ; 141.5 ; 155.6 ; 162.25 ; 167.75 \mathrm{pg} / \mathrm{mL}$ ) compared with abnormal postpartum estrus of Jawa Randu Goat $(109.9 ; 111.35 ; 101.2 ; 132.2 ; 142.45$ $\mathrm{pg} / \mathrm{mL}$ ). Mann Whitney U-test used for the abundance of cervical mucus and ferning showed non significantly different of postpartum estrus between both groups. Jawa Randu goats with normal PPE had a higher estrogen level than abnormal PPE goats. However, for the abundance and ferning of cervical mucus, between the two groups of goats was not different.

Keywords : Jawa Randu goat, postpartum estrus, estrogen, cervical mucus, ferning
\end{abstract}

\section{INTRODUCTION}

Animals living in tropical climates get heat stress. High temperatures affect the development of animal reproduction. The reproductive performance of animals in the tropics generally is determined by several factors, those are genetics, management, physical environment and nutrition (Smith and Akinbamijo, 2000). One of the factors determining the efficiency of animal reproduction is succes in observation of estrus appereance. Failure in estrus detection can lead to mating and pregnancy failure.

According to Hafez and Hafez (2000), estrus 
in goat is the period of time when the female is sexually receptive to buck. Goats are seasonally polyestrus. Estrus is correlated with the greatest ovarian follicular development and with enhanced release of estrogen. Estrogen, a female sex hormone from the ovary, acts on the female to cause the induction of behavioral estrus.

Previous study showed that interval from kidding to postpartum estrus (PPE) interval of Black Bengal goat ranged between 16-136 days with an average of 30 days (Chowdhury et al., 2002), while Murdjito et al. (2011) reported that Bligon goats showed postpartum estrus around 45-180 days with an average of 95 days. Knowledge of normal time of postpartum estrus is very important in the management of reproduction. The postpartum estrus is said to be normal if it occurs in most females.

Study on postpartum estrus relating to estrogen hormone level is lack. Of that reason, this study was conducted to determine the differences between normal and abnormal postpartum estrus based on the estrogen level in goat.

\section{MATERIAL AND METHODS}

\section{Materials}

Sixteen Jawa Randu Goats were used in this study with average weight of $35-45 \mathrm{~kg}$ and having second kidding period. The goats originated from 2 farmers group spreading over 2 villages, namely Pegongsoran and Penggarit Village.

\section{Experimental Design}

The Jawa Randu goats were divided evenly into two groups namely normal and abnormal postpartum estrus. Determination of normal postpartum estrus was chosen a goat having history estrus before 3 months after kidding. Moreover, abnormal postpartum estrus was goat having estrus after 3 months after kidding. This study animals were reared on intensively and feed concentrate as much as $200 \mathrm{~g}$ and $4 \mathrm{~kg}$ forage (field grass, gamal leaves (Gliricidia sepium) and lamtoro leaves (Leucaena leucocephala)) / head / day. Water was provided ad libitum. Goats was synchronized their estrus used progesteron hormone by vaginal sponge.

\section{Parameters Measured \\ Estrogen Hormone Level}

Blood sampling performed on day 0 (time of synchronized estrus), day 8 (mid of synchronized estrus), day 14 (end of synchronized estrus), day 16 and day 17. Blood was collected using a vacuum tube, $70 \%$ cotton and alcohol. Blood was drawn through the jugular vein in the neck of Jawa Randu goat. Blood was obtained in vacuum tube. It was centrifuged for 10 minutes at a speed of $2.500 \mathrm{rpm}$. Blood serum was analyzed using ELISA.

\section{Abundance of Cervical Mucus}

Observations on the ferning and abundance of cervical mucus were performed at the 18, 24, 33,42 and $48 \mathrm{~h}$ after the releasing of the vaginal sponge. Abundance of cervical mucus was observed the presence of mucus from the vulva, which were categorized into 4. Score 1: There was no mucus obtained, Score 2 : Cervical mucus appeared transparent, low quantity and hanging at the tip of the vulva, Score 3: Mucus was transparent, and the quantity being seen hanging from the vulva and around the tip of the tail, Score 4 : The mucus was transparent, the quantity abundance was found at the tip of the vulva, around the tail, around the thighs and up to the cage floor.

\section{Ferning}

Modified tools as the compose of a plastic sheath and syringe were used to collect the mucus from cervix. Mucus was dropped on top of glass objects then observed under the microscope. Assessment of cervical mucus ferning scores modifying from (Mardiati, 2003) categorized into 6 levels. The score of ferning was as follows: Score 1 : No ferning formed (no crystallization, a thick-walled structure in the form of air bubbles), Score 2 : Ferning formed in small and scattered pattern (there was only stems crystallization primer), Score 3 : Ferning formation consisting of stem ferning primary, secondary and tertiary (ferning covered less than half the field of view), Score 4 : Ferning formation consisting of stem ferning primary, secondary and tertiary (ferning covered than half the field of view), Score 5 : Ferning formation consisting of stem ferning primary, secondary and tertiary (ferning covered more than $75 \%$ of te area of the field of view), 6 : Ferning almost covering all the entire field of view (the formation of a fern leaf with the stem of primary, secondary and tertiary.

\section{Data Analysis}

Estrogen level was analyzed descriptively, whereas abundance and ferning of cervical data 
were analized by non parametric of Mann Whitney U-test.

\section{RESULTS AND DISCUSSION}

\section{Estrogen Level}

Estrogen level was the main parameter that used by previous researcher (Mayor et al., 2007; Siregar, 2009 and Widiyono et al., 2011) to examine the status of goats estrus. These hormone played a role in influencing several physiological changes in the goats when come into estrus phase. The estrogen level of normal PPE was higher than abnormal PPE of Jawa Randu goats.

Figure 1 shows that the estrogen level between normal and abnormal postpartum estrus (PPE) of Jawa Randu Goats relatively had a similar pattern. The average of estrogen level on normal PPE goats was higher (133.8; 141.5; $155.6 ; 162.25 ; 167.75 \mathrm{pg} / \mathrm{ml})$ than abnormal PPE goats $(109.9 ; 111.35 ; 101.2 ; 132.2 ; 142.45 \mathrm{pg} / \mathrm{ml})$. McDougall and Compton (2005) reported that estrogen had a dynamics throughout the estrus cycle. The dynamics of estrogen cycle was related to other hormones mechanism. Siregar (2009) reported that estrogen level of local goats was $62.21 \pm 12.86$ up to $79.89 \pm 14.41 \mathrm{pg} / \mathrm{mL}$.

Problem in follicular development might lead the lower estrogen level on abnormal PPE compared to normal PPE. Secretion of FSH was not optimum and led the disruption of estrogen secretion at follicle ovary. That condition was affected by secretion of gonadotropin-releasing hormone $(\mathrm{GnRH})$ that was not respond by anterior pitutary. Senger (1999) reported that low body weight, body condition and also stress of lactation or high prolactin levels were the reason of slow PPE.

Estrogen has a close relationship with the role of follicles in the ovaries. Inhibition of follicle development affected to the lower estrogen production. Estrogen located in the anthrum of follicle and produced by theca interna cells. Finally, estrogen was absorbed and circulated through the blood vessels to the target organ. Toelihere (1981) suggested that low levels of gonadotropin hormones mainly FSH may lead to postpartum ovarian hypofunction. Lower estrogen secretion by abnormal PPE led goats difficult to expresse the estrus signs as in normal PPE goats.

\section{Abundance of Cervical Mucus}

Estrogen increased during proestrus phase to estrus phase. This phase lead Jawa Randu Goats showed physiological changes in the reproductive tracks (mucus discharge and swollen vulva) and their behaviors (bleating, frequent tail wagging,

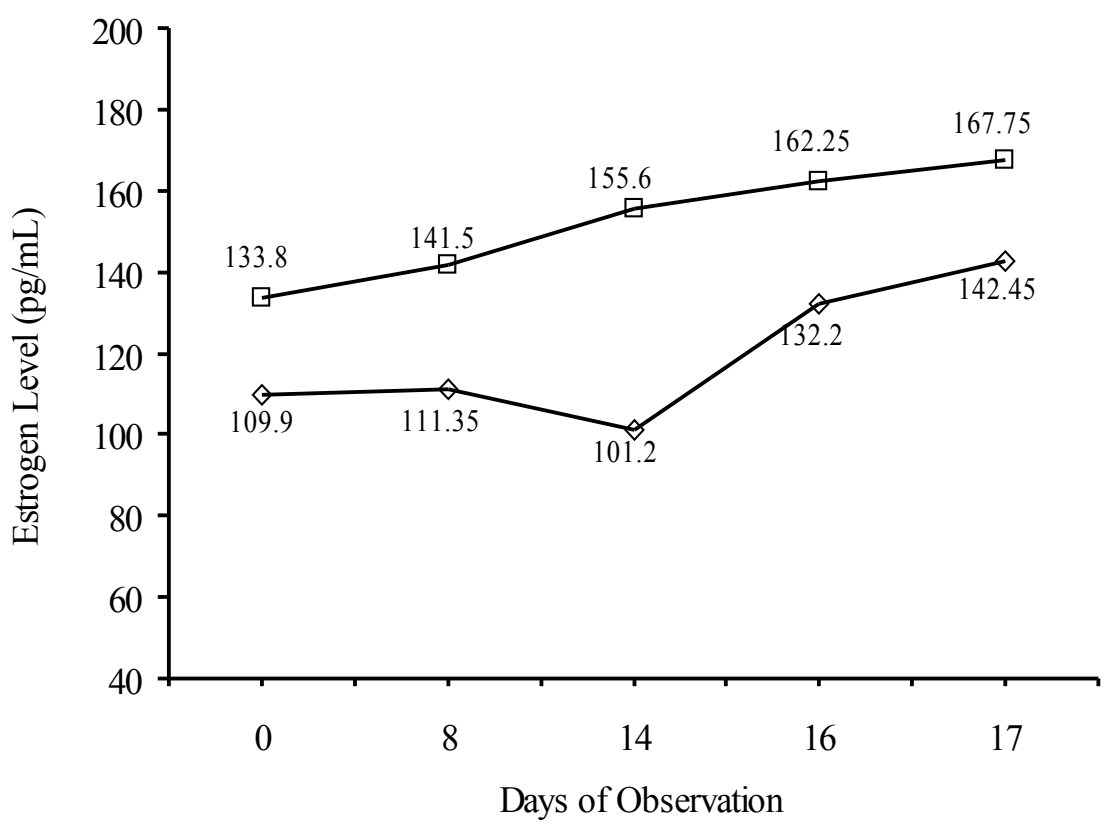

Figure 1. Estrogen Level of Jawa Randu Goats. $\square$ : Normal Pospartum Estrus; $\diamond$ : Abnormal Postpartum Estrus 


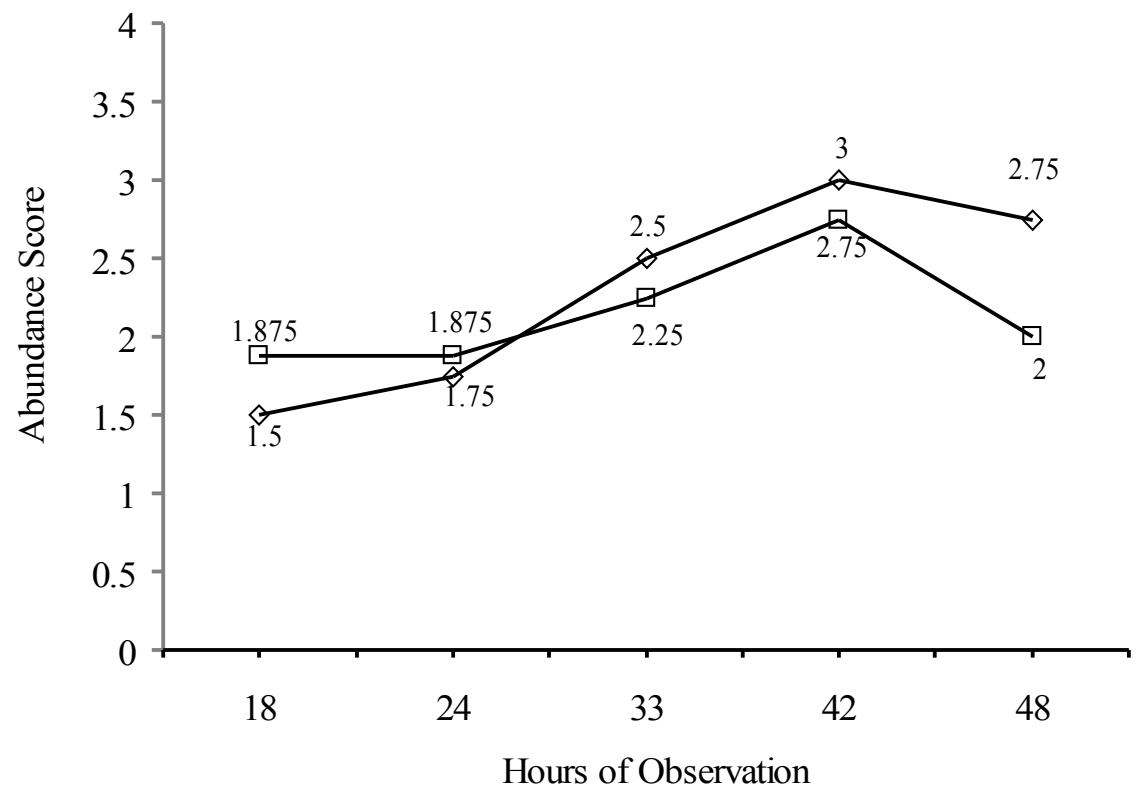

Figure 2. Abundance of Cervical Mucus of Jawa Randu Goats. $\square$ : Normal Pospartum Estrus; $\diamond$ : Abnormal Postpartum Estrus
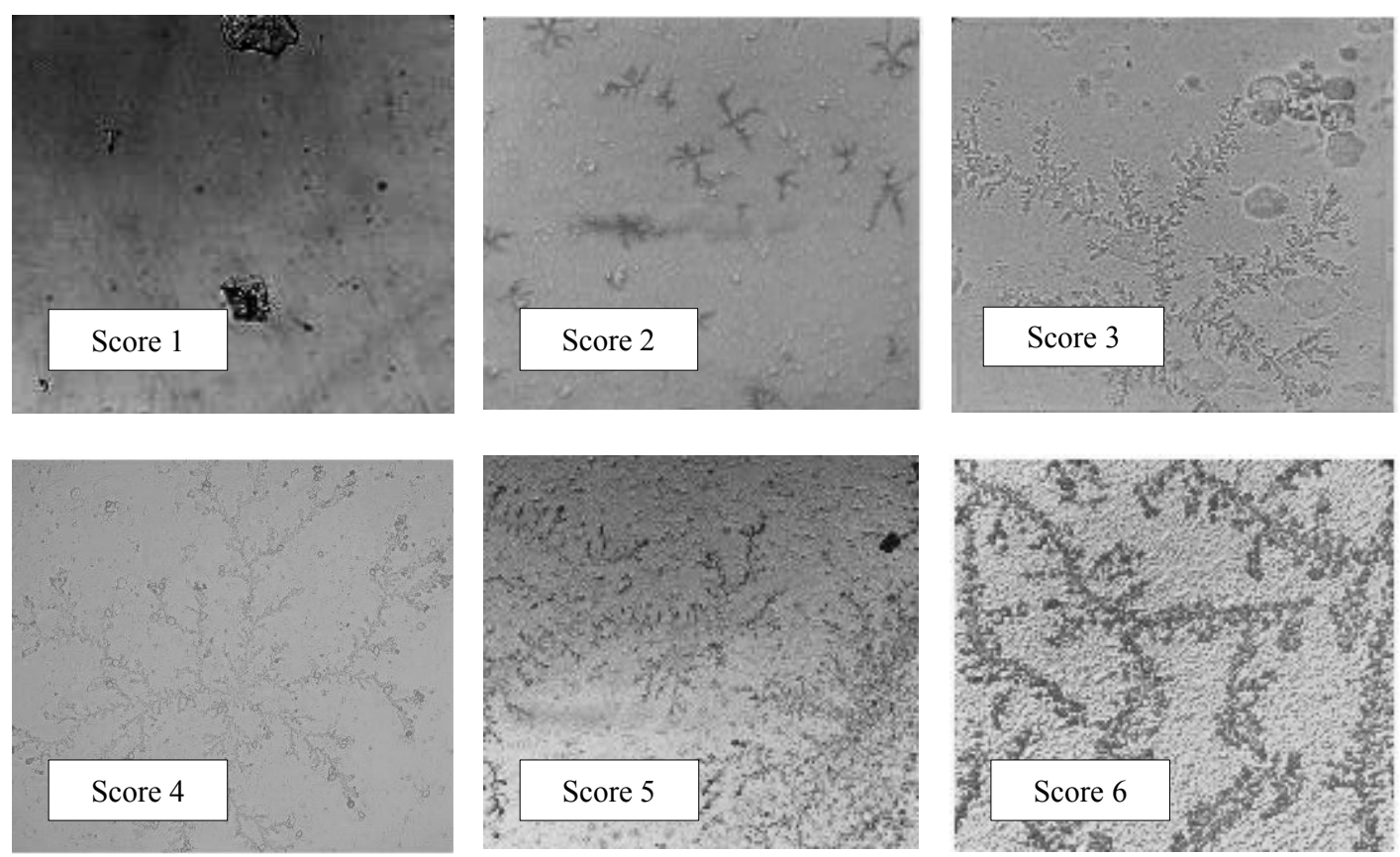

Figure 3. Ferning Crystallization of Jawa Randu Goats

pacing down the fence line and standing in heat). The results of this study indicated that different PPE had no effect on abundance of cervical mucus (Figure 2).
There was no significant difference of cervical mucus between normal PPE and abnormal PPE goats. The abundance of cervical mucus increased since 18 hours to 42 hours of 


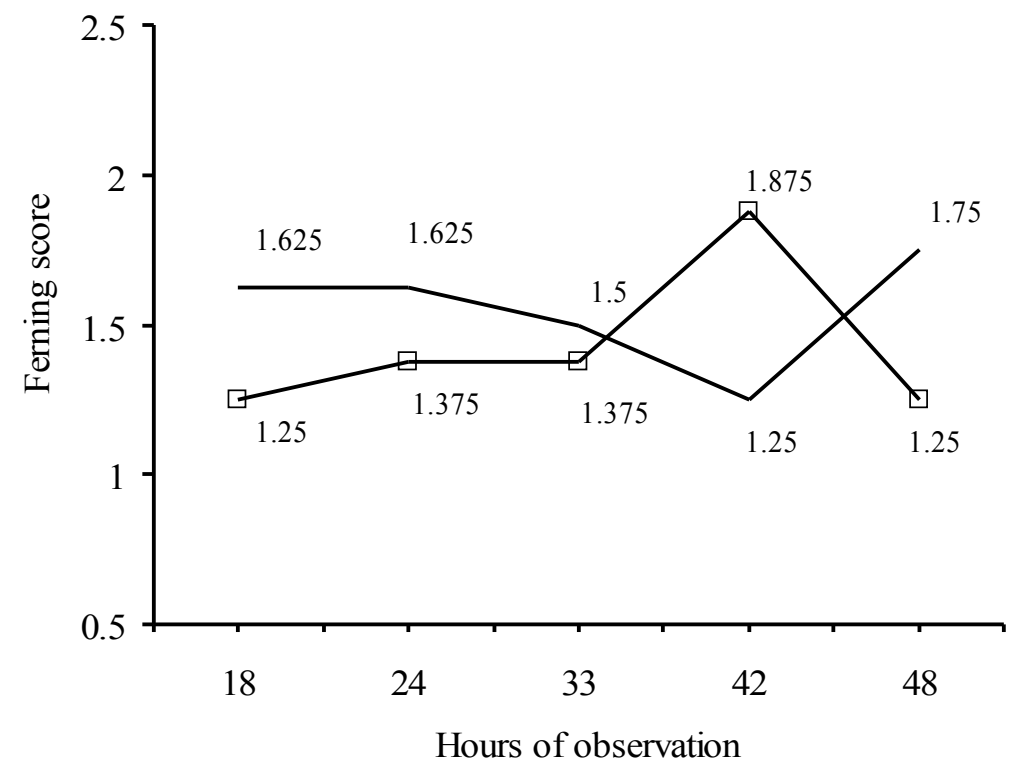

Figure 4. Ferning of Jawa Randu Goats. $\square$ : Normal Pospartum estrus; $\diamond$ : Abnormal Postpartum Estrus

proestrus phase and decreased at 48 hours due to estrogen. Cervical mucus was used for the preparation of the reproductive tract due to sperm deposition. It increased before ovulation occured. Cervical mucus was produced by cervix. According to Dewantiningrum (2008), the changes in the permeability of the cells in the cervix became more sensitive to stimulate gradient hydrostatics. The cervic cells became smaller than usual and followed by intercellular size, so that the higher permeability resulted in higher fluid drainage.

\section{Ferning}

Ferning was visible pattern in a dried specimen of cervical mucus. Ferning was the crystallization of sodium chloride in the cervical mucus under estrogen effect (Figure 3). Sutiyono et al. (2008) stated that the ferning of cervical mucus correlated with estrogen level.

There was no significant difference ferning of cervical mucus between normal PPE and abnormal PPE goats (Figure 4). Ferning of normal PPE goats raised gradually, beginning from 18 to 42 hours observation. This condition was not occurred at abnormal PPE goats because ferning raised gradually started from 42 hours of observation. This condition was affected to the estrogen level at the same time. Estrogen of abnormal PPE goats increased higher than normal
PPE goats. According to Mardiati (2003), the raised of cervical mucus production was followed by an increase in ferning of cervical mucus. Sutiyono et al. (2008) also reported that an increasing estrogen level and began the formation of follicle de Graaf affected the incidence rate of cervical mucus ferning.

\section{CONCLUSION}

Jawa Randu goats with normal PPE had a higher estrogen level than abnormal PPE goats. However, there was no differences in the abundance and ferning of cervical mucus between normal PPE and abnormal PPE.

\section{REFERENCES}

Chowdhury, S.A, M. S. A. Bhuiyan and S. Faruk. 2002. Rearing black bengal goat under semiintensive management physiological and reproductive performances. Asian-Aust. J. Anim. Sci. 15(4):477-484

Dewantiningrum, J. 2008. Perbedaan Pengaruh Clomiphene Citrate dan Letrozole terhadap Folikel, Endometrium dan Lendir Serviks Uji Klinik pada Wanita Infertil dengan Siklus Haid Tidak Teratur. Thesis. Diponegoro University, Semarang.

Hafez, B. and E.S.E. Hafez. 2000. Reproduction 
in Farm Animals. $7^{\text {th }}$ Ed. Baltimore, Lippincot, Williams \& Wilkins.

Mardiati, S.M. 2003. Kadar Na Lendir Serviks serta Kadar Garam Na dan K Lendir Mulut pada Berbagai Struktur Daun Pakis (Tes Ferning). Thesis. Universitas Diponegoro, Semarang.

Mayor, P.H., D.A. Galvez, E. Gimaraes, L. Galius and M. Loper-Bejar. 2007. Serum estradiol 17 beta, vaginal cytology and vulval appearance as predictor of estrous cyclicity the female collared peccary (Tayassu tajacu) from estern Amazon region. Reprod Sci. 97: 165-174

McDougall, S. and C. Compton. 2005. Reproductive performance of anestrous dairy cows treated with progesterone and estradiol benzoate. J. Dairy Sci. 88:2388

Murdjito, G., Budisatria, Panjono, N. Ngadiyono and B. Endan. 2011. Kinerja kambing bligon yang dipelihara peternak di desa Giri Sekar, Panggang, Gunung Kidul. Buletin Peternakan. 35(2):86-95

Rao, S. 1997. Genetic Analysis of Sheep Discrete Reproductive Traits Using Simulation and Field Data. Dissertation. Virginia
Polytechnic Institute and State University, Blacksburg, Virginia.

Senger, P.L. 1999. Pathway to Pregnancy and Parturition. Current Conception Inc, Washington.

Siregar, T.N. 2009. Profil hormon estrogen dan progesteron pada siklus berahi kambing lokal. J. Ked. Hewan. 3(2):240-247

Smith, O. B. and O. O. Akinbamijo. 2000. Micronutrients and reproduction in farm animals. J. Anim. Reprod. Sci. 60 : 549-560.

Sutiyono, E.T. Setiatin, S. Kuncara and Mayasari. 2008. Pengaruh pemberian ekstrak hipofisa terhadap birahi dan fertilitas pada domba yang birahinya diserentakkan dengan progesteron. J. Indonesian Tropical Animal Agriculture. 33(1):20-26

Toelihere, M.R. 1981. Ilmu Kemajiran pada Ternak Sapi. Institut Pertanian Bogor, Bogor.

Widiyono, I., P. P. Putro, Sarmin, P. Astuti and C.M. Airin. 2011. Kadar estradiol dan progesteron serum, tampilan vulva dan sitologi apus vagina kambing Bligon selama siklus birahi. J. Vet. Sci. 12(4):263-268 